\title{
NOTES
}

\section{NEWSPAPER-RADIO JOINT OWNERSHIP: UNBLEST BE THE TIE THAT BINDS*}

Common ownership of two or more sources of mass information 1 has been accelerating in recent years through acquisitions by newspapers of local radio stations. ${ }^{2}$ This development is particularly disturbing since over-all competition in the distribution of news and opinion has been suffering from creeping atrophy.

Contemporary surveys indicate that of the 1394 communities with daily

* Mansfield Journal v. FCC, 180 F.2d 28 (D.C. Cir. 1950).

1. The owner of a news distributing medium places the imprint of his predispositions upon the news by virtue of his selection of the news events to be featured and the manner of their presentation. By extending his control to other media, he extends the scope of a single partisan selection, thereby excluding other, different ideas from the arena of public opinion. See Judge Learned Hand in United States v. Associated Press, 52 F. Supp. 362, 372 (S.D.N.Y. 1943), aff'd, Associated Press v. United States, 326 U.S. 1 (1945).

Consequently, the FCC position in the Mayflower case, 8 F.C.C. 333 (1941)-the broadcaster must be impartial in his overall presentation of public issues-is extremely difficult to carry out. See Your NewsPaper 25 (Swirsky ed. 1947). That this is recognized by the FCC may be inferred from its attempts to allocate broadcast licenses to different persons within a community. See, e.g., Easton Publishing Co., 4 Prke \& FischeR RADIo REg. 176 (1948) rev'd and remanded on other grounds, 175 F.2d 344 (1949); James A. Noe, 3 Pike \& Fischer Radio Reg. 1821 (1949). Cf. Midland Broadcasting Co., 3 Pike \& Fischer Radio Reg. 1961 (1948). For a discussion of present patterns of broadcaster evasion of the unreal "fairness" formula of the Mayflozecr doctrine, sce Notc, The Mayflower Doctrine Scuttled, 59 YALE L.J. 759, 767 (1950); Note, Radio Editorials and the Mayflower Doctrine, 48 Cos. L. Rev. 785, 792 (1948).

While the Commission on the Freedom of the Press felt that diversity of outlook was important, it thought diversity did not necessarily depend upon facts of ownership. Nevertheless, in one situation-cross-channel ownership within a community-the Commission concluded that diversity would be seriously curtailed. ChafEe, 2 Govennanent ANv Mass Communicatrons 623, 655 (1947). See also the testimony before the Press Commission of the Nieman Fellows, id. at 520; Fly, Freedom of Speech and the Press, in SAFEguarding CiviL Liberties Today 61, 68 (Sabine ed. 1945). The newspaper industry's leading spokesman has concurred with this position. Editor \& Publisher, Dec. 31, 1938, p. 20. This problem was explored during the newspaper-radio investigation conducted during 1941-42. See Hearings before the FCC in re: Orders 79 and 79-A, Docket 6051, Exs. $397-9,416-18$.

2. The problem has been important for some time. See Shapiro, The Press, the Radio and the Law, 6 AIR L. Rev. 128, 153 (1935). In 1934, many independent station owners feared that the entire industry might be taken over by the newspaper industry. Newsweek, June 16, 1934, p. 28. By 1937, the FCC was seriously concerned. Opinion of FCC General Counsel Gary, February 13, 1937 reported in Warner, Radio and TELEvision LAw 207 n.3 (1948). Four years later, the Commission began a full scale investigation. See note 26 infra. For a study of the increase in newspaper-owncd stations, see notes 8 and 9 infra. 
newspapers, ${ }^{3}$ only 117 have two or more competing. ${ }^{4}$ And except for the nation's twenty-four largest cities, there has been a tendency to eliminate competition completely. ${ }^{5} \mathrm{~A}$ compensating trend in radio has failed to develop-out of 1300 cities with radio stations, only 30 per cent have competing outlets. $^{6}$ Viewing both media together, more than seventy per cent of the

3. The census defines a community as an incorporated place with a population of 2500 or more. Each community, whether or not it comprises part of a metropolitan area, is treated as an entity. There were 3,459 communities in the United States in 1940. XVIth Census of the United States-1940, 1 Population 25 (1942). Since then, 67 new communities have come into existence. Communication to the YalE LAW Joursisl from T. J. Slowie, Secretary, FCC, dated December 7, 1949, in Yale Law Library.

These communities have 1770 newspapers. Nixon, The Problem of Neresfaper Monopoly in Mass Connsunications 158 (Schramm ed. 1949). Today, there are 830 less newspapers in the United States than in the peak year of 1909 when 2600 were published. Although the number of cities with newspapers has increased since that time, the ratio between newspapers and communities has steadily decreased. It was 3.4 in 1910; 2.6 in 1920; and 1.7 in 1930. Lee, The Dany Newspaper in Aarerica 65-6 (1937).

4. Another 174 cities have two or more newspapers, either jointly owned or managed in such a way as to potentially eliminate competition. Of these, 161 are single owner cities. In the other 13, the two existing dailies have entered into partial combinations which place their business offices on a non-competitive basis. Nixon, Concentration and Absenteeism in Newspaper Ouncrship, 22 JourNalisar Quarterly 97, 101 (1945).

There are only 1300 newspaper owners. And 91.6 per cent of the 1394 daily newspaper cities had a single publisher. Nonetheless, 58.8 per cent of the total circulation is competitive, for most of the daily circulation is in the larger communities where competition still exists and probably will continue to thrive. Nison, The Problem of Neusfaper Monopoly in Mass Coxarunications 158 (Schramm ed. 1949).

5. This trend works to eliminate all but one newspaper in towns of less than 50,000 population, to combine two papers under one publisher in cities of 50,000 to 400,000 and to maintain competition only in cities of more than 400,000 population. Ibid.

The distribution of daily newspaper competition by cities as of Janaury 1, 1948 was:

$\begin{array}{lccc}\text { Size of City } & \text { Total Cities } & \text { Competitize } & \text { Percentoge } \\ \text { With Dailies } & \text { Cilics } & \text { Complifitic } \\ \text { Less than } 10,000 & 547 & 14 & 2.6 \\ 10,000-50,000 & 656 & 37 & 5.6 \\ 50,000-100,000 & 94 & 15 & 16.0 \\ 100,000-200,000 & 51 & 20 & 39.2 \\ 200,000-300,000 & 17 & 6 & 35.2 \\ 300,000-400,000 & 12 & 8 & 66.7 \\ 400,000 \text { or over } & 17 & 17 & 100.0\end{array}$

Communication to the Yale Law Journal from Prof. R. B. Nixon, Professor of Journalism, Emory University, dated December 4, 1949, in Yale Law Library.

6. In 1949,378 of the 1,311 communities possessing broadeasting facilities had competing stations. Communication to the Yale LAw Journal from T. J. Slowic, Seeretary, FCC, dated December 7, 1949 in Yale Law Library. These communities had 2,179 standard (AMI) stations and 865 frequency modulation (FMI) stations. The overwhelming majority of commercial FMI stations were authorized to AMI licensees and were jointly operated, so that programs broadcast over the AM stations were transmitted simultaneously by the FM station. 15 FCC ANN. REP. 40, 53 (1950).

In 1948, 356 communities had competing stations. Of these, 156 had two stations, 87 had three and 133 had four or more. In the Matter of Editorializing By Broadeast Liecnsecs, Offictal Report of the Proceedings Before the Federal. Cosarumications Cosassissios: Docket No. 8516, Exhibit 26 (1948). 
communities with dailies also have at least one radio station. ${ }^{7}$ But 407 of the radio stations are affiliated with local newspapers, ${ }^{8}$ and there are 170 "one-to-one" cities where the only radio station is affiliated with the only newspaper. ${ }^{9}$ With such a limited number of mass media, these markets bear scant resemblance to the ideal of "the widest possible dissemination of information from diverse and antagonistic sources" within a community. ${ }^{10}$

Application of the antitrust laws by the Department of Justice is one possible remedy for the restrictions imposed by cross-channel ownership. ${ }^{11}$ Antitrust law would compel divestiture if absorption of a radio station was

7. At least one newspaper and one radio station exist in 989 communities. Data compiled from Broadcasting Magazine Yeatiook 69-325 (1950) and Ayer \& Son's Directory of Newspapers and Periodicals 1165-88 (1950).

8. The figures for previous years are as follows:

$\begin{array}{lccc}\text { Year } & \text { Affiliated } & \text { Total } & \text { Per cent } \\ 1931 & \text { Stations } & \text { Stations } & \text { Affiliatcd } \\ 1935 & 55 & 612 & 9.0 \\ 1939 & 104 & 605 & 17.2 \\ 1941 & 184 & 764 & 24.1 \\ & 211 & 801 & 26.4\end{array}$

Based on statistics presented in Hearings before the FCC in re: Orders 79 and 79-A, Dockct No. 6051, Exs. 1, 3.

9. This represents a substantial increase over the number of local communications monopolies existing in 1941. At that time, 351 of the 801 stations were located in "one-toone" comunities. In 111 of these, the only radio station was owned by the local newspaper, and in three cities the only two radio stations were owned by the only local newspaper. Hearings before the FCC in re: Orders 79 and 79-A, Docket No. 6051, Ex. 8, Table Ia. Today, 623 of the 1,311 cities have only one radio station and one newspaper; in 170 of these cities, they are jointly owned. In 75 other communities, the single newspaper owns one of the two radio stations. Statistics on the contemporary situation are compiled from BrosDcasting Magazine Yearbook 521-26 (1950) and Ayer \& Son's Directory of Newspapers and Pertodicals 1165-88 (1950).

10. Associated Press v. United States, 326 U.S. 1, 20 (1945).

It has been said that the paucity of local media is overcome by the number of available outside media: stations located in nearby towns; regional and clear-channel stations; and newspapers. But these media do not fulfil the same function as local media. Since ench community has peculiar local problems which are of little concern to outside media, there must be diversification on the local level just as there must be diversity on the regional and national level. See dissent in Stephen R. Rintoul, 3 Pike \& Frscher RAdro REg, 96, 99 (1945) (Commission approved transfer of only local radio station to only local daily where the community was serviced by a number of media originating in an out-of-state metropolitan area). See also Editor \& Publisher, Dec. 31, 1938, p. 20. Cf. Plains Radio Broadcasting Co. v. FCC, 175 F.2d 359 (D.C. Cir. 1949). The Commission has taken this factor inta account. See Communications Act of $1934 \S 307$ (b), 48 STAт. 1083 (1934), as amended, 50 Stat. 189 (1937), 47 U.S.C. $\$ 307$ (b) (1946) (hereinafter cited as the Communications Act), which was controlling in Samuel R. Sague, 3 Pike \& Fischer Radio Rec. 694 (1947). Accord, Huntington Broadcasting Co., 5 Pike \& Fiscuen Radio Reg. 721 (1950).

11. The Communications Act specifically provides that the granting of a license shall not estop the United States from proceeding against the licensee for violation of the antitrust laws. Communications Act § 311 . 
the result of coercive tactics on the part of a newspaper, or if joint ownership was used to exclude disfavored advertisers or to sell them time and space only at unduly high rates. ${ }^{12}$ Generally speaking, divestiture is also in order where joint ownership carries with it the power to exclude actual or potential competitors, or where its dominance is such as to deprive consumers of any real alternatives. ${ }^{13}$ But it is at least doubtful that mere common ownership of a radio station and newspaper in a single town would violate the antitrust laws. ${ }^{14}$ It is even more doubtful that common ownership of two out of three or four media would constitute a violation, even though the public interest in diversity of news sources is to a considerable extent compromised.

Practical considerations also weigh heavily against undue reliance on this means of enforcement. The funds available to the Antitrust Division are likely to remain meagre in relation to the job assigned to it. ${ }^{15}$ Except where

12. United States v. Crescent Amusement Co., 323 U.S. 173, 189 (1944); Schine Chain Theatres v. United States, 334 U.S. 110, 128 (1948).

13. See United States v. Paramount Pictures, 334 U.S. 131 (1948) (monopoly power, whether lawfully acquired or not, may violate Section 2 of the Sherman Act); United States v. Griffith, 334 U.S. 100 (1948) (monopoly even though no showing of intent to establish a monopoly where the monopoly results as a consequence of buying power); Rostow, Monopoly under the Sherman Act: Pouter or Purpose?, 43 ILL. L. Rev. 745 (1949).

Hence, the data prepared by the Office of Radio Research to indieate that there was very little difference between associated and non-associated stations in the number of news programs, their distribution through the day or in general program structure may be irrelevant. Hearings before the FCC in re: Orders 79 and 79-A, Docket No. 6051, Exs. 385-7. But see note 14 infra.

14. The Supreme Court has defined the area of the market wherein control is alleged as the zone of immediate competition for the product. See Mfandeville Island Farms v. American Crystal Sugar Co., 334 U.S. 219 (1948) (market for sugar beets in a small area in northern California) ; United States v. Columbia Steel Co., 334 U.S. 495 (1948) (market for rolled steel in an eleven-state area); United States v. Yellow Cab Co., 332 U.S. 218 (1947) (taxi-cab market in Chicago).

It might be argued that in the communication field the product is local news and the market is the community. But compare the following statement: "Anyone who owns and operates the single theater in a town, or acquires the exclusive right to exhibit a film, has a monopoly in the popular sense. But he usually does not violate $\$ 2$ of the Sherman Act unless he has acquired or maintained his strategic position, or sought to expand his monopoly, or expanded it by means of those restraints of trade which are cognizable under $\$ 1 . "$ United States v. Griffith, 334 U.S. 100, 106 (1948).

15. The Antitrust Division of the Department of Justice has never been equal to the task of policing the entire economy. Before 1939, its staff never included more than 60 lawyers; today, it has no more than 200 . And not until 1940 did. it ever receive an appropriation of $\$ 1,000,000$. Limitations of personnel alone have made it impossible to continue beyond the investigation stage every inquiry disclosing practices which are questionable under the federal antitrust laws. A careful process of selection forces the Division to consider the advantage that will be secured if the action is successful and the effeet of such action on future antitrust law enforcement. See Walton Hasrilton, Patrensis of CossPETrTION 59 (1940); Berge, Some Problems in the Enforement of Antilrust Lat, 38 Misce. L. REv. 462, 475 (1940) ; Fowler Hamilton, The Selection of Cases for Mfajor Investigation, 7 Law \& Contentporary Problexrs 95, 96 (1940). 
national monopoly is involved, the Division necessarily tends to tackle only selected offenders rather than an entire industry. ${ }^{16}$ It would be virtually impossible to effect a uniform policy on cross-channel ownership by such procedures. Moreover, it seems undesirable to divert the energies of the Antitrust Division from the vast unregulated areas of the economy into a field already subject to supervision by another federal administrative agency.

Administration action by the Federal Communications Commission, therefore, is a more promising answer to the problems presented by newspaper-radio mergers. The FCC is empowered to grant, renew or revoke broadcasting licenses. ${ }^{17}$ In exercising that power, it is confined by a statutory guide no less broad than the "public interest." 18 And ever since the

16. See, for example, the Antitrust Division's pattern of attack on the movie industry. It moved against all major producers and distributors, United States v. Paramount Pictures, 334 U.S. 131 (1948), but only against selected chain exhibitors. No attempt has been made to deal with the problem of local monopolies. But see the civil antitrust suit instituted against the Lorain Journal Co. in the United States Court for the Northern District of Ohio. United States v. Lorain Journal Co., Civil Action No. 26823 (filed September 22, 1949) (attempt to monopolize the sale of mass advertising in the Lorain-Elyria area).

17. Communications Act $\$ \S 307,309$ (a), 312(a). The FCC can exercise broad discretion in determining whether grant of a license will be in the public interest. Sce, c.g., FCC v. WOKO, 329 U.S. 223 (1946). The Commission can engage in widespread investigations to secure the necessary information for a proper discharge of its functions. Stahlman v. FCC, 126 F.2d 124, 127 (D.C. Cir. 1942) ; FCC, PudLic SERviCe Responsidility of Broadcast Licensees 54 (1946). Renewal applications are to be governed by the same considerations as applications for new licenses. Communications Act $\$ 307$ (d). The grant of a license to a broadcaster gives him no property right in the allocated channel. Sce Trinity Methodist Church v. FRC, 62 F.2d 850, 853 (D.C. Cir. 1932); Yankec Network v. FCC, 107 F.2d 212, 215 (D.C. Cir. 1939). While this power cannot be exercised without reason, the Commission can refuse to extend the franchise when the operation of the station is not in the public interest. Evangelical Lutheran Synod of Missouri v. FCC, 105 F.2d 793, 795 (1939).

Renewal proceedings furnish the FCC with an opportunity to submit the liccnsce's operation of the station to a comprehensive evaluation. In the case of AM stations, this opportunity occurs once every three years. 47 Code FED. REGS. $\$ 3.34$ (1949). FM licenses are granted for a lesser period. Id., \$3.218. While the Commission can terminate the franchise at any time during its life, it has been chary in the use of this power, having utilized it only twice in 23 years. Station WSAL, 8 FCC 34 (1940); Station KPAB, 5 P1ke \& Fischer Radio Reg. 1297 (1950). See Note, 15 Geo. Wash. L. Rev. 425, 429 (1940). The major difference between denial and revocation proceedings lies in the placing of the burden of proof that station operation will be in the public interest. In the latter, unlike refusals to renew, the Commission must show that operation is not in the public interest. See WARNER, Radio and Television Law $\$ 12(\mathrm{~g})$, (1948).

18. Communications Act $\$ \S 151,301$. See Yankee Network v. FCC, 107 F.2d 212, 222 (D.C. Cir. 1939). See also SEN. Rep. No. 772, 69th Cong., 1st Sess. (1926) (statentent of the objectives of the Radio Act of 1927, precursor of the present act). Congress imposed upon the Commission the duty of protecting the public interest in the use of the common property-the broadcast channels. Communications Act $\$ 301$.

Abandonment of the principle of restraining government action in matters involving the press resulted from the singular nature of the broadcasting medium. Only in radio is the number of available channels subject to physical limitation. Even today, despite the threc- 
National Broadcasting Company case, ${ }^{19}$ the term "public interest" has included the policies of the antitrust laws. ${ }^{20}$

In a recent case, Mansfield Journal v. FCC, ${ }^{21}$ the Commission has for the first time denied a broadcasting license to a newspaper on antitrust grounds. Upon investigation and hearing, the Commission found that the Journal, Mansfield's only newspaper, had sought to suppress competition in the dissemination of news and to achieve an advertising monopoly by attempting to drive out the only other local mass medium-radio station WMAN. Because these past practices presaged future abuse, the Journal's application was denied. ${ }^{22}$ On appeal, the Court of Appeals for the District of Columbia approved both the ruling and the grounds on which the ruling was made. ${ }^{23}$

But more important, the court indicated that the Commission in the exercise of its licensing power could look to a much broader range of considerations than the unseemly behavior apparently indulged in by the applicant in the Mansfield case. The decision not only implied that a license

fold increase in commercial broadcasting stations since 1945, the number of qualificd applicants exceeds the number of available franchises. 15 FCC ANs. REP. 36 (1950).

19. National Broadcasting Co. v. United States, 319 U.S. 190 (19:3).

20. "A licensee charged with practices in contravention of this standard cannot continue to hold his license merely because his conduct is also in violation of the antitrust laws and he has not yet been proceeded against and convicted. By clarifying in Section 311 the scope of the Commission's authority in dealing with persons convicted of violating the antitrust laws, Congress can hardly be deemed to have limited the concept of 'public interest' so as to exclude all considerations relating to monopoly and unreasonable restraints upon commerce. Nothing in the provisions or history of the Act lends support to the inference that the Commission was denied the power to refuse a license to a station not operating in the public interest merely because its misconduct happened to be an unconvicted violation of the antitrust laws." National Broadcasting Co. v. United States, 319 U.S. 190, 223 (1943).

Earlier, the Commission, relying upon Section 313, had said: "The prohibitions of the Sherman Act apply to broadcasting. This Commission, although not charged with the duty of enforcing that law should administer its regulatory powers with respect to broadcasting in the light of the purposes which the Sherman Act was designed to achieve." FCC, Report on Chain Broadcasting 46 (1941). The FCC has also taken official notice of the policies of the Sherman Act when regulating the telephone and telegraph industries under the grant of power contained in Section 151 of the Act. See, c.g., Western Union Division v. United States, 87 F. Supp. 324, 334 (D.C. Cir. 1949), affd per curiam, 338 U.S. 864 (1950). See also MIcLean Trucking Co. v. United States, 321 U.S. 67 (1944); New York Central Securities Corp. v. United States, 287 U.S. 12 (1932).

21. Mansfield Journal Co., 3 PIKe \& Fiscrier RAdro Reg. 2014 (1948), sib nom., Mansfield Journal v. FCC, 180 F.2d 28 (D.C. Cir. 1950).

22. The components of the Commission's decision are inextricably entangled. The Commission referred to its determination that diversification of the control of mass media was desirable; applicant's past record; and the possibility that applicant would extend his present course of action into the future if the application were granted. Whether the decision that the grant would not be in the public interest rests on the past practices or applicant's probable future operation of the station is not clearly stated. Mfost probably, it rests on both.

23. Mansfield Journal v. FCC, 180 F.2d 28 (D.C. Cir. 1950). 
could be denied if the grant would help achieve a monopoly; ${ }^{24}$ it also sustained the Commission's power to consider monopolistic practices of the applicant whether or not they would constitute violations of the antitrust laws. ${ }^{25}$ It seems probable, therefore, that where appropriate the Commission can deny or revoke a license on a showing, without more, that common ownership will operate or has operated to reduce the diversity of news sources which "public interest" requires.

So far, the power has not become a practice, ${ }^{26}$ though in recent competitive hearings the FCC has favored non-newspaper applicants. ${ }^{27}$ Rather, analysis of cases since the Stamford decision ${ }^{28}$ of 1945 indicates that the Commission's primary considerations in licensing are the degree of identification of the applicant with the community to be served; the probability that those in control will devote their full efforts to the station; the extent of previous experience in radio, particularly within the community involved; and the scope of the proposed service. ${ }^{29}$ Apparently the issue of joint ownership is controlling only when scrutiny of these factors has failed to produce a decision. ${ }^{30}$

Since its power to incorporate the spirit as well as the letter of antitrust law into its regulation is now firmly established, the Commission should turn the Mansfield approach into a continuing policy. Wise administration might call initially for a rule which would in substance forbid newspaper ownership of radio stations where the effect would be to create a monopoly or substantially to lessen competition in the mass dissemination of news. ${ }^{\text {at }}$

24. Id. at 33,34. The court cites with approval that section of the Chain Broadensting Report which asserts the power of the Commission "to refuse licenses or renewals to any person who engages or proposes to engage in practices which will prevent either himself or other licensees from making the fullest use of radio facilities." (emphasis added). FCC, Report on Chain Broadcasting 83 (1941).

25. 180 F.2d. 28,34 (D.C. Cir. 1950).

26. The Commission has granted newspaper applicants both standard and FM licenses in non-competitive hearings. See WaRner, Radio ANd Television LAW $\$ 22(\mathrm{~g})$. It has also granted franchises to newspapers in competitive hearings. Hamden-Hampshire Co., 4 Pike \& Fischer Radio Reg. 504 (1949) ; Town Talk Broadcasting Co., 3 Pike \& Fisciuen Radio Reg. 769 (1947) ; Orlando Daily Newspapers, 3 Pike \& Fiscirer Radio Reg. 624 (1946). Cf. Midland Broadcasting Co., 3 Pike \& Fischer Radio Reg. 1961 (1948).

There have been no attempts at dissolution for this cause since the investigation of newspaper ownership began in 1941. For the inconclusive statement of policy issucd after the conclusion of the hearings, see 9 FEd. Reg. 702 (1944). See also Brucker, Frezdon OF INFORMATION 83 :(1949).

27. See, e.g., Fairfield Broadcasting Co., Pike \& Fischer Radio Reg. 190 (1949); Southern Tier Radio Service, 3 Pike \& Fischer Radio Reg. 211 (1946).

28. Stephen R. Rintoul, 3 Pike \& Fischer Radio REg. 96 (1945).

29. See cases cited in notes 26 and 28 sipra.

30. See Warner, Radio and Television Law $\$ 22$ (g) n.13 (1948).

31. The Commission's powers are to be utilized to further "the public interest." Communications Act, $\S 303(\mathrm{~g})$. The courts have upheld the grant of broad discretion to the FCC to determine the most effective means of promoting this standard. See Ward v. FCC, 108 F.2d 486, 491 (D.C. Cir. 1939). The value of enacting rules to articulate the standards 
The rule would serve principally as a mere statement of policy, ${ }^{32}$ since the FCC must grant a hearing before denying a license. ${ }^{33}$ But past experience proves that an indication of policy often has a prophylactic effect. ${ }^{36}$

With or without a rule, however, effective enforcement of the policy will depend on regular scrutiny of the non-competitive aspects of cross-channel ownership in all licensing hearings. Depending on the status of the news-

for measurement of license applicant qualifications has been recognized. Heitmeyer v. FCC, 95 F.2d 91, 98 (D.C. Cir. 1937). Administrative Proccdure in Goecrnment Agencics, SEm. Doc. 8, 77th Cong., 1st Sess. 27 (1941). The rule-making power has broad limits because the intent of Congress was to grant the Commission "expansive powers." National Broadcasting Co. v. United States, 319 U.S. 190, 219 (1943).

32. Compare the Chain Broadcasting Regulations upleeld in the NBC case. National Broadcasting Co. v. United States, 319 U.S. 190 (1943). Justice Frankfurter, who had dissented in the CBS case, Columbia Broadcasting Co. v. United States, 316 U.S. 407, 429 (1942), from the majority holding that the Regulations, 47 CopE. FED. REGS. $\$ 3.101-3.103$ (1949), automatically denied a license to any station acting in derogation of their command, restated his original view. "[The regulations] are merely an announcement to the public of what the Commission intends to do in passing upon future applicants for license. ... No announcement of general licensing policy can relieve the Commission of its statutory obligation to examine each application for a license." Id. at 431.

If the order is no more than a general statement of policy, it may not be subject to prior judicial review. Urgent Deficiencies Act, 3S SrAT. 219, 220 as incorporated and extended by Communications Act $\$ 402(\mathrm{~b})$. Where the order sought to be reviewed does not of itself adversely affect complainant, but will only affect him if the agency uses it as a basis for action against him, resort to the courts is either premature or wholly beyond their province. Rochester Telephone Co. v. United States, 307 U.S. 125, 130 (1939). But see Columbia - Broadcasting Co. v. United States, 316 U.S. 407, 416 (1942).

These requirements will make it virtually impossible to secure review before the Commission acts on an application for renewal since the FCC has refused to issue declaratory judgments under the power granted it by $\$ 5$ (d) of the Administrative Procedure Act, 60 Stat. 239, 5 U.S.C. $\$ 1004$ (d) (1946). See Cross-out Advertising Co., 5 Pike \& Fiscmen RAdio REg. 464 (1949).

The promulgation of rules would not only serve as an indication of the Commission's stand on the matter, but would also allow the industry a chance to present its side of the controversy. The right of interested persons to adequate notice and hearing is guaranteed in rule-making proceedings. Administrative Procedure Act $\$ 4,60$ SrAr. 237, 5 U.S.C. $\$ 1001$ (d) (1946). These rights only apply to "substantive rules, which involie true administrative legislation." SEN. Doc. No. 248, 79th Cong., 2d Sess. 19 (1946). In all probability, the proposed rule would bear a substantive tag. Nathanson, Some Commeris on the Adninistrative Procedure Act, 41 ILL. L. Rev. 368, 382 (1946).

33. Communications Act $\$ 309$ (a). This section not only gives the Commission authority to grant licenses without a hearing, but it also enables a license applicant to request a hearing as of right before his license is denied. Ashbacker Radio Co. v. FCC, 326 U.S. 327 (1945).

34. Licensees have always been extremely jittery when dealing with the Commission. In the back of their minds is the omnipresent threat of license revocation. Accordingly, rules and even informal utterances by the FCC or its individual members have often been followed instantly by conformance to the new pattern. See Comment, Adminis/ralize Enforcement of the Lottery Broadcast Prozision, 58 YaLE L. J. 1093. 1110 (1949). But compare the action of the industry when faced with the Chain Broadcasting Regulations. Wuite, The Axierican Radro 162 (1947). 
paper applicant, the power may be exercised through original denial of a license, or through revocation or refusal to renew. Depending on the case, withholding of a license may be based on one of three grounds. First, monopolistic practices engaged in by the applicant in the past may be chalked up as a poor character qualification. ${ }^{35}$ Second, the Commission may find that cross-channel ownership has violated or is likely to violate the antitrust prohibition against monopoly power. Third, the Commission may find that such ownership, while not violating antitrust law, is nevertheless inconsistent with the "public interest" in getting as much diversity as is possible. ${ }^{36}$

In some cases, joint ownership of a newspaper and radio station will not be contrary to the public interest. Small communities, where the need to promote diversity may be the greatest, often possess insufficient resources to support competing information outlets. ${ }^{37}$ Enforcing competition here, without regard to economic consequences, might only destroy one or both media. ${ }^{38}$ And perhaps in some large cities sources of information may be so numerous that the effect of occasional cross-channel ownership may be inconsequential.

A thorough but flexible application of the Mansfield doctrine would contribute substantially to the public's interest in widely diversified control over the instruments of mass communication. ${ }^{39}$

Howard N. Gilbert

35. Communications Act $\$ 308(\mathrm{~b})$. See note 20 supra. Compare Mester v. United States, 70 F. Supp. 118 (E.D.N.Y. 1947), aff'd per curiam, 332 U.S. 749 (1947) (dcnial of application for transfer of station franchise based in part on prospective transferce's record of federal regulatory law violations). Compare also Southern Steamship Co. v. NLRB, 316 U.S. 31 (1942). Here, the Court set aside an NLRB order issued without Board consideration of a relevant criminal statute. "... [T] he Board has not been commissioned to cffectuate the policies of the Labor Relations Act so singlemindedly that it may wholly ignore other and equally important Congressional objectives. Frequently, the entire scope of Congressional purpose calls for careful accommodation of one statutory scheme to another, and it is not too much to demand of an administrative body that it undertake this accommodation without excessive emphasis upon its immediate task." Id. at 47.

36. If the Commission is to carry out the program contemplated herein, it should have some means at its command to allow the licensee a period of grace before the franchise is discontinued. Issuance of a cease and desist order would enable the licensee to securc a purchaser before final proceedings to cancel the license were instituted. The FCC has requested Congress to provide it with the power to issue cease and desist orders. See Hcarings Before Committee on Interstate and Foreign Commerce on H. R. $1973 \S 312(\mathrm{~b}), 81 \mathrm{st}$ Cong., 1st Sess. 20 (1949).

37. See Report of the U.S. Senate, Special Committee to Study Problems of American Small Business, Survival of a Free Competitive Press, The Small Newspaper, U.S. Senate, 79th Cong,, 1st Sess. (1947) ; FCC, An Economic Study of Standard Brondcasting, esp. 59-97 (1947).

38. See Chafee, 2 Government and Mass Communications 660, 662 (1947).

39. While the Commission is capable of carrying out a program to climinate crosschannel ownership it may be worthwhile to determine if Congress will support such action. Congressmen are particularly sensitive about any inroads on the broadcaster's privileges, for 